\title{
Churchill Show: Transgressing language codes and upsetting stereotypes Patrick Chesi Lumasia
}

\section{Churchill Show: Transgressing language codes and upsetting stereotypes}

Cultural productions on television and/or online platforms are immensely prolific at expressing the peoples' every day and the historical. They provide platforms on which actors express themselves on their own terms, in their own language codes and styles with little censure. With the proliferation of digital technologies and the advent of the internet and attendant new media, the production, circulation, and consumption of cultural texts on the (Eastern) African scene has radically shifted and continues to grow in ways unimagined before. In Kenya specifically, with an exponential growth of television channels, numerous local cultural productions continue to burgeon, carrying with them a constellation of voices that are representative of the country's socio-cultural and linguistic diversity. These productions not only entertain, but also explore critical issues in Kenyan society and beyond. Among them is Churchill Show, which through an aesthetics of escapism, (re)narrates quotidian events and recuperates and (re)interprets the country's historical trajectory. Moreover, the show oftentimes embodies a political aesthetics cloaked in postmodern humour that serves to recalibrate common/sensical perceptions as well as the regimented practices and ways of knowing. Thus, the show transgresses language codes and upsets socio-psychological stereotypes, for which it is often condemned, to shape a new notion of 'Kenyanness'. Keywords: Churchill Show, aesthetics of escapism, transglossia, political aesthetics, postmodern humour, 'Kenyanness'.

\section{Introduction}

In this article I argue that the Kenyan stand-up comedy programme Churchill Show, besides entertaining its audiences, addresses serious issues in Kenyan society through an aesthetics of escapism. I opine that the comedy show continues to free constellations of youthful voices that are expressive of the peoples' quotidian and the historical in a hypermediate manner. By employing transglossic language practices, Churchill comedians transgress language codes and upset stereotypes via a political aesthetics of postmodern humour. After situating the show in an aesthetics of escapism using "Churchill Show: Moi Day edition", I analyse three more routines: one by employing a transglossic framework; two to demonstrate how Churchill upsets stereotypes to fashion a new Kenyan spirit of 'we-ness' among the ordinary peoples.

\section{Churchill Show and an aesthetics of escapism}

Churchill is a general exhibition stand-up comedy that premiered in September 2008 as Churchill Live, rebranding into Churchill Show and Churchill Raw in 2012. The former features established comedians; the latter upcoming talent. It is hosted by Daniel Ndambuki ('Churchill') in Nairobi and tours the country twice a month. ${ }^{\text {P Produced by }}$ Laugh Industry Ltd., Churchill is broadcast every Sunday between 8:00 and 9:00 pm East African Time on Kenya's Nation Television (NTV) and uploaded on YouTube by either NTV or "Churchill Show". The show begins with a theme song: "Bringing Kenyans back together [...] Jamii zote pamoja" (all communities [back] together), which is significant owing to the fact that the show was founded in 2008, the year Kenya experienced the worst post-election violence in its recent history following the disputed 2007 presidential election. The song therefore marks the show as saliently political.

Subsequently, the show is branded as 'more than just comedy', implying that it aims at more than just exciting amusement and laughter from the Kenyan people. I contend that to effectively address socio-economic and

Patrick Chesi Lumasia is a final year PhD student in the department of literary studies at Rhodes University, South Africa. His interests are in Kenyan comedy and humour studies.

Email: ricklumasia@gmail.com

(D) https://orcid.org/0000-0001-9740-3559

DOl: https://doi.org/10.17159/tl.v58i1.8256

DATES:

Submitted: 28 April 2020; Accepted: 24 February 2021; Published: 12 May 2021 
political issues without courting state censure, Churchill employs an aesthetics of escapism. William Paul explores this aesthetics in romantic comedies "as something other than pleasant diversions from serious concerns" (274). To this end, Paul attempts to disinvest the term 'escapism' of its negative connotation of being antithetical to 'realism' by suggesting that as a narrative mode, "escapism of necessity inscribes a reality" (276). He argues that for us to understand 'escapism', we must know what it is we are escaping from and to. In my case, answers to these questions provide access to the fantastical world of Churchill in that the specifics of the escapism, as Paul writes in his context, "are a product of its time, and in these specifics we can locate the reality the escapism references, the social order that its comic utopia seeks to counter" (276). Churchill is hence aesthetically escapist in so far as referencing the country's quotidian and historical trajectory. In "Churchill Show: Moi Day edition", for instance, Churchill transmogrifies its stereotypical self, dispensing with its perceived raw material of socio-psychological stereotypes about ethnicities to (re)interpret the Moi epoch (Laugh Industry, "Churchill Show: Moi edition"). The show takes place in an archetypal 'Moi day' sitting room, embellished with crochets, which only dressed the furniture on special occasions such as Christmas and visitations from long lost relatives, and a 'Great wall' television set, which was exclusively operated by mzee (Kiswahili for family patriarch). Anyone else operated the set under his strict instructions; otherwise, they received a terrible beating.

The terror referenced is truly reflective of the nature of fathers of the Moi era-1978 to 2002. Captain Otoyo, a comedian on the show, underscores how parents were bizarrely 'disciplinarian'. Children were to be seen and seldom heard; just as the overall Kenyan subjectivities were under Daniel Moi, Kenya's second president who was accorded the respectful Swahili honorific of Mzee (among several others). Mzee's word, however illogical, was law to which everyone submitted. This does not necessarily mean that only Moi was dictatorial. Jomo Kenyatta (Kenya's founding president) was too, as Shilaho (51) notes; only, the said edition specifically references the Moi epoch. Churchill establishes a nostalgic mood of the time by leading the audience in singing "Uvivu ni adui mkubwa kwa ujenzi wa taifa" (Laziness is the greatest enemy to nation-building), a popular song by a section of Kenya's military, the Maroon Commandos, that played on the country's state and sole broadcaster, the Kenya Broadcasting Corporation (KBC), every morning at six, immediately after the national anthem. It urged everyone-from the farmer through the clerical officer to the school-going child-into hard work in the nation-building project.

After an interlude of musical entertainment interspersed with commercial advertisements, the 7:00 pm newscast followed. Churchill reads this in present time while impersonating Leonard Mambo Mbotela, a legendary Kenyan broadcast media personality, intimating that all news segments - main, business, sports, and even the weather forecast-revolve(d) around the president. In other words, His Excellency the president was virtually the news; the news presented him as the omnipresent 'patriarch of the nation'. The Kenya Times newspaper, owned by the Kenya African National Union (KANU), Kenya's sole political party then, was the Paper and the ultimate bearer of Truth. KANU was then described as chama ya baba na mama (father and mother's party), a description spearheaded by the president himself as the party leader. Every voter was obligated to enlist as a member at an annual subscription fee and pledge their loyalty to KANU. As Charles Hornsby argues, Kenya was a party state (398). The country's loyalty pledge to the president and the republic was accordingly amended to include Moi's Nyayo philosophy of peace, love, and unity, which signalled his attempt to "build a legitimating ideology" based on Christian principles that he passionately defended (348). Moi never missed a church service, a ritual that always found its way into the news as a first item every Sunday. The 1980s witnessed widespread political repression in Kenya, with fundamental freedoms, rights, and liberties suppressed and denied as Moi tightened his grip on power after the 1982 failed coup attempt (9-10). Opposition parties were banned and Kenya became a de jure single party state in 1982. "Opposition to the government was treated as subversion, and the sole criterion for political success became loyalty to the president" (398), which buttressed the "Big Man" syndrome and its attendant personality cult culture: the evils that seem to stalk the country to-date (Shilaho 75).

Churchill juxtaposes the historical with the quotidian by introducing a platoon of 'slay queens' (and 'slay kings') to the president. Their clarion call is "No finance, no romance". Attendant, too, are socialites led by Vera Sidika and Huddah Monroe. "Slay queen" is colloquial for a 'good time girl' who engages in compensatory and transactional relationships with elderly well-to-do men, or 'sponsors', for their money for flashy lifestyles in a consumerist society. Her male counterpart is the slay king, who resonates with the South African phenomenon of Ben 10 (Ligaga, Women, visibility and morality in Kenyan Popular Media 100). Dina Ligaga reads Sidika and Monroe as "hypervisible" Kenyan celebrities/socialites who represent "difficult women" with regard to their body "exhibitionist performances and self-representations online" in defiance of "heteropatriarchal norms of morality" (126). 
Indeed, Churchill claims that the two and their kind are famed for disregard for clothing and for their artificial beauty, largely frowned at by the 'patriarchal police'. Prevalent among university female students, the slay queen phenomenon is not without its downside in regard to sometimes exposing young women to violent death as happened to Sharon Otieno, whom Otoyo mentions just as Ligaga acknowledges (Women 113). Ligaga argues that these kinds of women "use their [feminine] vulnerability as a location of strength" (122), further contending that these women's behaviour embodies "transgressive femininity". Much as such reading speaks to new Kenyan femininities, the "cautionary tales" attached to the lifestyle paint it as dangerous and undesirous.

Comedian MCA Tricky comments on how slay queens live carefree lives ostensibly intended to trap 'sponsors' with pregnancies aimed at opening cash taps in the form of child support. The wily old men then turn to gruesome murders to eliminate them and the unborn babies as apparently happened with Otieno. In other words, slay queens are not so astute; they are just as gullible as they were as children when Moi used to fool them with milk to attend school. MCA Tricky extends the metaphor to belittle them, an element he shrewdly turns around to address contemporary political developments in the country. Another comedian, Johnny Boy, further draws out the metaphor to opine that if the devil's seat fell vacant, Kenyan politicians would contest for it. He seems to suggest that the Kenyan politician typifies the devil at whose mercy the citizenry finds itself. Thus, Churchill is the ordinary peoples' political programme that implicitly counters the divisive and exploitative narratives propagated by the state and/or the political class. In other words, whereas the show remains comedic, its routines are interspersed with (re)interpretations of the quotidian and the historical that speak to the salience of alternative histories as conceived by the ordinary people themselves; hence fashioning a new notion of 'Kenyanness'. As Kimani Gecau argues, such histories and memories can only be channelled through the popular arts that chronicle and "mediate popular experience and constitute a very important element in the circulation of ideas and formation of opinion outside the official and mainstream media and channels" (29). Therefore, Churchill offers an alternative and prolific avenue, where a galaxy of comedians recuperates repressed histories and memories to (re)construct a sense of themselves that is cognisant of the ordinary peoples' shared past, common present, and a projected fruitful future devoid of biological/'tribal' essentialisms.

It must be remembered that Churchill was a member of the defunct make-belief comedy troupe of Redykyulass of the late 1990s that Grace Musila acknowledges "contributed towards the unmasking of state power, fracturing of the culture of fear and ultimately popularized a culture of critique of the workings of state power" (295). With his stage mantra, which speaks to an ostensibly worn people, Churchill seems to be continuing the work of Reddykyulass with the aim of attempting to heal a people divided by statist machinations that have roots in the colonial experience and are propagated through 'tribal' politics often based on stereotypes that portray some communities as hardworking and fit to lead and others as lazy and unfit (Atieno-Odhiambo 243; Ligaga, "Ethnic stereotypes and the ideological manifestations of ethnicity in Kenyan cyber communities" 82). Thus, Churchill (re)narrates and (re)interprets daily and historical events on a weekly basis through an aesthetics of escapism with the aim of rebuilding an otherwise politically fractured nation.

\section{The transglossic language of Churchill Show}

As stand-up comedy, Churchill's ultimate objective is to elicit laughter. Consequently, it manipulates language by employing devices characteristic of verbal play such as punning, intonation, and metathesis and ethnic and/ or other accents, often accompanied by non-verbal reinforcements such as gestures and mime. Satire, irony, sarcasm, contrast, and hyperbole help comedians caricature and parody those in authority and dexterously address serious societal concerns. Importantly, Churchill comedians ingeniously draw on the country's linguistic ecology of polyglotism in a manner that executes an implicit political aesthetics that transgresses linguistic codes through transglossia.

According to OfeLia García, transglossia refers to "the fluid, yet stable, language practices of bilingual and multilingual societies that question traditional descriptions built on national ideologies". The notion, the sociolinguist argues, "has the potential to release ways of speaking of subaltern groups that have been previously fixed within static language identities and hierarchical language arrangements that are constrained by the modern/colonial world system" (108). As they are under no illusions of being policed by Kenya's postcolonial language policy makers, the youthful comedians largely sidelined by the state not only imitate speech patterns from various locations and cultures, but also execute them as they are practised in everyday life and, in a way, 
translocate the language of the 'streets' onto the comedic stage, thereby circumventing official 'censorship' to carve out a peculiar notion of 'Kenyanness'.

Taking cue from García, Sender Dovchin, Alastair Pennycook, and Shaila Sultana prefer 'transglossia' to Mikhail Bakhtin's 'heteroglossia'. The sociolinguists argue that transglossia makes possible the combination of "heteroglossic and transanalytic approaches and [...] draws attention to the transgressive ways in which voices operate" (104). They justify their preference with reference to recent translingual research in applied linguistics, which "indicates that language is ecologically embedded and interconnected with diverse semiotic resources" (94) that "occur across and within languages" (93). In other words, with the advent of globalisation and the complexities that characterise language acquisition in bilingual and multilingual societies such as Kenya, it is impractical to look at languages as autonomous systems because cultural contact and language interactions result in "multiple modes of semiotic diffusion", which cannot be adequately analysed under the auspices of code-switching/mixing and hybridity (93).

Sultana and Dovchin further vouch for transglossia because the variation in voices warrants both translocalisation and transculturation which, respectively, entail "drawing on linguistic and cultural resources from multiple locations [and] on multiple cultural resources" (70). With this concept, they contend, speakers "unravel the transgression in voices not so much in linguistic features, but in translocalization, transculturation, and transtextualization (deploying a range of meaning-making practices across languages)" (70). Accordingly then, transglossia "underscores the importance of mixing and blending and the way they engender new meanings" (67), which I argue is precisely the case in Churchill.

Simply put, the comedians eclectically employ language by adopting various voices from multiple socio-cultural and geographic locations while drawing from a wide range of linguistic and cultural resources within and without Kenya's borders. This engenders a linguistic synthesis beyond code-mixing/switching and hybridity in which languages and language practices are mixed and meshed by way of quoted and recycled speech, mimicry, and parody and employed to fashion a new notion of Kenyanness-a liberal Kenyan speech community on their own terms as opposed to that advocated by the state. Such language practices can only be effectively deciphered through a transglossic framework, which "leads to in-depth understanding of contextual (physical location and participants), pretextual (historical trajectory of texts), subtextual (ideologies mobilized by the texts), intertextual (meanings that occur across texts), and posttextual interpretations of the data (the ways texts are read, interpreted, resisted, and appropriated)" (72).

I employ this framework to validate this section's claim. From the "All white edition" I quote David's routine (and those further on) at length for context and the attendant analytical reference. This particular episode is so named because of the colour of dress of both the comedians and the audience. Churchill sets its transglossic tone by blending myriad voices in English and Kiswahili to show the differences in speech patterns of Kenya's social classes, reggae fans, and visitors from Seattle in the US. He also employs 'Indian'-accented English to welcome the Indians present, to whom he refers as "our friends" while assuring them that they will get the jokes as some will be made in "Indian". However, the show proceeds in Kiswahili/English predominantly, with an occasional dose of Sheng, leaving the Indians to their own devices.

Routine 1:

Font guide to languages: Kiswahili (bold), English (regular font), Sheng (italics), mixture/meshed (italics bold)

Lupita is the only Kenyan lady with natural hair. Kuna wenye wako na natural hair hapa? For real? [...] Lupita alikam, akaenda mbaka Kisumu. Na akiwa Kisumu mahawker walienda naye huko. Mahawker tu hawa wetu wa Muthurwa. Hawkers that sell nothing. Wako hapo: Oscars 150. You see, Oscars 150. Oscars 150. Namaanicha avocado na kashubari. You know, Lupita is nurtured. What do I mean by 'Nurtured'? 'Nurtured' ni mtoto mwenye anaeza argue na budake. For example, Lupita aliambia budake, "I wanna be an actor". And the father was saying like, "Ok, I don't know. You wanna be an actor. It's ok; it's fine. We gonna argue about that". Watoi wa Westlands huwa wana-argue na buda zao [...] wanaargue! Kayole huwezi argue. Unaweza-argue na budako? Ati, "Eh mmzae, maze joh, mimi naona tusikule cabbage, tukule sukuma coz ya heartburn". Immediately, mzae anakwambia, "Unargue na mimi? Yaaah! Unajaribu kunioneshaa, unaeza handle landlord, si ndiyo? Ni uhame. Shika keja yako. Kila mtu na maisha yake". Budaangu hunge-argue na yeye! For example, babangu alikuwa anasupport Manchester. Sisi wote tulikuwa Manchester damu. You know mpaka (ok Mii ni wa Arsenal) Manchester ikifunga, tulikua [...] We are forced to celebrate: goaaal! Because he's watching. Kuna siku Arsenal ishawahi funga na kitu ikanidanganya niruke nayo: goal! Nilimpata ameningoja hivi. "Irianza rini? Hiyo pepo ya Arsenal". Akaturnia mama yangu, "Sinasemanga mimi ni Manshester damu. Hii damu ni ya nani?" 
Are there any Kenyan ladies with natural hair? [...] Lupita came and went up to Kisumu. Muthurwa hawkers followed her there to sell nothing but Oscars for 150 shillings. I mean, avocado and onion and tomato salad! Lupita is nurtured. A nurtured child is the type that can argue with the father. Lupita told the father, "I wanna be an actor". Westlands children argue with their fathers. They argue! In Kayole, you cannot argue. Can you argue with your father? "Eh, old man, I think we should eat cabbage and not kales to avoid heartburn". Immediately, the old man tells you, "Are you arguing with me? Yeah, you're trying to show me that you can handle the landlord, right? You have to move out. Go rent your place. Everyone on their own". You couldn't argue with my father. For example, my father used to support Manchester [United]. We were all compelled to become Manchester United diehard fans [to conform]. I'm an Arsenal fan, but whenever Manchester United scored, we were forced to celebrate: goal! Because he's watching. There's a day Arsenal scored and something lied to me to jump up in celebration: goal! On coming down, I found him waiting for me like this (gesticulates how). "How did it start? That Arsenal evil spirit". He turned to my mother, "I have always insisted I'm Manchester by blood. Whose blood is this?" (Laugh Industry, "Churchill Show-All white Edition”, my translation)

The pre-textual reference is made to Lupita, the daughter of the current Kisumu county governor, Anyang Nyong'o. She won an Oscar for her supporting role in Steve McQueen's 12 Years a Slave and was named People magazine's most beautiful woman in 2014 (Jordan and Antoinette n. p.). David's exaltation of her as the only Kenyan lady with natural hair is laced with both sub-and post-textual references, which he invokes to chastise Kenyan ladies for wearing synthetic hair. He demonstrates this contextually by pointing to unnatural hair in the audience and quickly 'takes' Lupita to her home county of Kisumu. Post-textually, the question David seems to be posing is: Why would Kenyan ladies struggle to sport natural hair while one of their own is doing exceedingly well in the United States with her natural hair? Contextually, the hawkers exploit the euphoria the Oscars occasioned, turning it into a buzz word that references a post-textual castigation of cosmetic beauty and unnatural hair, which he means should be disposed of.

David moves to the social class gulf existent in the country, which is quintessentially sub-textual. Lupita belongs to the higher stratum of society by parentage. She is 'nurtured', David intimates; she can argue with the father about her choices in life. The manner of her speech and career choice are revelatory. The language is American English-accented, the career a not-so-conventional one. The language is shared by the father, who is accommodating of her rather 'odd' career choice. Her peers in Kayole, a low-class settlement in Nairobi, have no such luxury. They cannot even escape the pains of heartburn by making a choice between eating cabbage and kale. The 'authoritarian' fathers have the exclusive say in the regimented lives of the Kayole youths, who have not the luxury of even basic life choices such as food. Just for raising the suggestion of the choice of what to eat, the youth of a Kayole parent is taken to be questioning the authority of the father, and is harshly advised to move out as he is assumed to be qualified to afford to pay his own rent. The Kayole family's choices are not only limited in so far as food (and shelter); their language does not stretch beyond Sheng. Whereas Sheng is largely conceived of as a language of the youth, in Kayole the father and youth speak it indiscriminately to each other. This construction has obvious subtextual connotations. Like the Kenyan Asians (and Caucasians) in this episode, the mothers in these two instances are conveniently erased. They have no say in the family decisions, which paints Kenyan society not just as predominantly black African, but also patriarchal.

David, an Arsenal fan, and the whole household had no choice but to follow the father's choices. No choice dramatizes this absurdity better than the father's team choice: Manchester United, an English team. David could have used Gor Mahia and AFC Leopards, Kenya's foremost football giants with a rivalry stretching back to their founding in the 1960s. Notwithstanding, his choices for his father and himself seem to speak to Kenyans' passion for the English Premier League, and particularly these two teams, whose rivalry is similar to Gor Mahia and AFC Leopards', only longer. David's support of Arsenal is significant enough to make the father question his paternity. The mother is under attack for the son's pastime choices. It is worth noting that David quickly slips from Sheng into Gikuyu-inflected Kiswahili for his family set-up, such that even the 'ch' in Manchester comes out just as inflected: 'sh'. These are subtextual references locating him as a fluid subjectivity.

This is revelatory of the language of Churchill on the whole. Much as it is heteroglossic to the extent of capturing the variety of speech patterns explored in the respective voices, it is transgressive in that it does not use languages as autonomous systems in their standard forms. Because of the bilingual nature of Kenya's public space, English and Kiswahili are often mixed and switched between in conversations. The youthful demographic spices up the mixture with Sheng: "a mixed code based on Kiswahili, English and local languages" (Wanjala 81). With its origins in Nairobi's Eastlands area, Sheng is fast spreading to whole parts of the country. Thus, much as comedians quote, recycle, and reproduce speech patterns and voices of various personalities and speech communities, 
they not only draw extensively on the country's translinguistic and transcultural ecology, but also mimic and parody the English, Kiswahili, Sheng, and vernacular codes in a transgressive fashion, which speaks to a different speech community than that regimented by the state and its language gatekeepers. These language practices are meant to elicit laughter. However, when critically examined, the transglossic language practices manifest a desire to break free from the regimentation of the post-colonial state and its agencies in order to fashion and entrench an alternative, 'freer' linguistic and cultural sensibility. Sheng thus establishes group identity and empowers its speakers, marking them out from other groups (see Wanjala 86).

Since Sheng cannot be ascribed to any given ethnicity, its use on Churchill attests to the comedy's attempts to resist narrow ethnic ascriptions as well as the constricting hegemonies of English and Kiswahili. Therefore, as Joyce Nyairo and James Ogude contend, Sheng marks its users as a generation in search of home and belonging, keen to borrow and blur ethnic identities and boundaries while fusing them with cosmopolitan discourses. And if indeed Sheng "best carries the weight of quotidian existence [and] longings for better tomorrows" (396), then it is definitive of "Kenya's Transnation", as Wanjala (88) argues, that connotes our notion of a new Kenyanness. In other words, Sheng constitutes a fluid Kenyan subjectivity (or ethne) that oscillates between the nation's geographies, cultures, ethnicities, and concepts while resisting grounding in any one of these categories. It could be one viable escape from the country's 'tribalism' woes that are steeped in exclusionary indigenous languages that English and Kiswahili have failed to stem.

\section{Upsetting stereotypes: The political aesthetics of Churchill Show}

Postmodernity is saturated with media technologies that are disruptive to age-old epistemes, perceptions, and the commonsensical. Humour of the kind that is prevalent on Churchill is consonant to such a conjuncture and can be termed as postmodern because it is amenable to the sensibilities of postmodernism. According to Nicholas Holm, postmodernism is an "often ill-defined and frequently overburdened" critical term that can nonetheless "do particularly pertinent theoretical work in terms of the political aesthetics of contemporary humour as a site of openness, imprecision and reflexivity in relation to formal conventions" (195). The humour thus questions totalising grand narratives and stretches boundaries between the real and the aesthetic to the extent of collapsing them (195). In other words, such humour not only makes it difficult to differentiate between the real and the referents thereto, but also holds them in a tension hard to resolve. As such, the humour makes us encounter the world as we might a text, and a text as we might the world; leading to confusion, anxiety, and even reactionary politics (196).

To belabour the point, the humour nearly collapses the distance between the material and the artistic worlds, making them appear conterminous and co-extensive in a tense relationship that the audience is arguably hard put to navigate. That is to mean that much as the humour derives from real experiences and/or perceptions, it is constructed in a manner that blurs the boundary between the 'real' and the construction obtaining therefrom such that the audience is simultaneously in the real and the aesthetic worlds. With the burden of resolution thus heavily weighing on them, the audience has to defer to "extra-textual codes of social judgement" in which it is implicated (115). The funniness of the humour then depends on how much each member is caught up in the content. Therefore, although (some) members may laugh, the laughter is inflected with a searing doubt as to whether they are laughing at the real (and, therefore, themselves) or the comical as jumbled up in the text since the incongruous and the butt(s) are not clearly differentiated.

This is significant because Churchill is often accused of entrenching ethnic stereotypes, which supposedly jeopardise ethnic relations in the country. Some critics go so far as recommending that the audience be made aware that the stereotypes are for comical purposes - as if this is not obvious already — and are not to be taken seriously (Ndonye, Bartoo and Khaemba 605). Intriguingly, some even call for governmental regulation for their use and complete abandonment (Ndonye, Yieke and Onyango 58). Such critics seem not to realise that the stereotypes are relayed through inoffensive humour, often forging group solidarity (Githatu and Chai 566), indexing 'Kenyanness' and diffusing inter-ethnic tensions (Michieka and Muaka 559). It might help if the critics saw the play on them as executed in mock-signification in order to draw the attention of the political elite to Kenya's socio-cultural and political predicament. ${ }^{2}$

Be that as it may, the humour is saturated with doubt because competing frames of reference overlap with each other, with none emerging as the dominant or standard against which a deviation is to be made. The referents of the text and the epistemes that structure them are thus destabilised. Consequently, the taken for granted perceptions imbedded in stereotypes are upset and so is the logic that engendered them because it is subjected 
to scrutiny amidst mirth. What materialises in a sustained manner beyond the laughter is ambivalence. As Holm argues, "it is this unsettling of categories that emerges as the political meaning of the aesthetic logic of contemporary humour, and which therefore renders it a political aesthetic form, regardless of what occurs at the level of content" (194). In other words, the form of the humour supersedes the content, which is often assumed to be nothing but stereotypes.

The critics might need to call on the postpositivist realist theory of identity to make sense of the pastiche accruing from the blurring of boundaries between the real and the aesthetic. The theory neither essentialises nor dismisses identities, but believes that they can be both real and constructed, and that understanding them is paramount so that that they are not reified but transformed and, if needs be, dismantled. The point is, as comedians enact their own/representative experiences and prevalent perceptions/conceptions, they (un)consciously assume or choose (for targets) between real and constructed identities for "complex subjective reasons that can be objectively evaluated" for progressive politics (Moya 9). The politics might not be radically transformative as the humour is not a priori determined as political, but it nonetheless unsettles common perceptions and understandings of the world by subjecting them to relentless interrogation geared towards contesting and renegotiating power relations (Holm 12).

In simple terms, humorous texts do the political work of unsettling our prevailing sensual, commonsensical, and epistemic perceptions, (re)defining and (re)distributing them anew. Thus, the political nature of the humour can only be unveiled upon examination of specific and contextual humour texts because the humour springs from the material world and, therefore, addresses real issues and real people and their real and constructed categories-race, ethnicity, gender, religion, sexuality, region, and class-into which they fall, by ascription or otherwise. These categories have ramifications on the distribution of goods and resources and the relationships individuals forge with their fellow human beings because these are embedded in societal structures of power responsible for social liberation and/or oppression (Moya 8).

This point is pertinent particularly to Kenya, where ethnicity is not only "a factor in political competition and in the allocation of national resources" (Shilaho 2), but also a determinant in public affairs, where something as basic as the spelling of one's name could easily decide their fate since ethnic identity seems to trump all other identities. With the belief that "subjectivity or particularity is not antithetical to objective knowledge but constitutive of it", postrealists affirm that "identities are not something to transcend or subvert but something we need to engage with and attend to" (Moya 17). Therefore, it sounds myopic to advocate for governmental regulation of socio-cultural stereotypes - the fodder of comedy - and naive to call for their abandonment altogether. The following routines suffice to make my point. For limitations of space, I only give my own English translation.

Routine 2:

If we (Somalis) try dancing in public, people start warning each other of imminent danger. I wonder what wrong we committed against you guys. People just have a negative mentality towards Somalis; that Somalis are dangerous. But it is true! We are those bad ones. That's why I keep telling you, if you happen to sit next to a Somali on a matatu, just start a conversation with them. Ask them about the weather, if they think it will rain tomorrow'. Emphasise "tomorrow". Their response should determine your next move. If they tell you that it can rain [...] just ensure you have an umbrella. Know you are safe. However, if they tell you, "It can rain now, perhaps at night, it can rain anytime, but who tells you, you'll see tomorrow?", alight immediately! It's not safe. [...] We're good people, but this mentality has limited us on the things we can say in public. For instance, as a comedian, you crack the best of jokes at which the audience cracks up. You exit, excited, saying, "I killed it!, I have killed". Recently, after giving my best at a show, I went out and made a call: "'ve finished KICC! I've killed. People are being collected from under the seats! There is even one fellow who was crying, pleading with me not to continue. But who am I? I killed that one, mercilessly". Imagine, I didn't complete that call. A G4S guard apprehended me and took me to Central police station to finish my story from there. (Laugh Industry, "Churchill Show S7EP30 KICC")

Nasra Yusuf, Kenya's only Somali comedienne on Churchill, problematises the material and the aesthetic. Somalis are seldom seen dancing in public. She couples this reality with the stereotype that Somalis are dangerous, which she 'validates' in her first punchline: "Ni ukweli; sisi ni wale wabaya!" (It is true, we are those bad ones!) Note that the 'validation' does not use the word "dangerous", but "bad", infusing it with ambivalence. Moreover, it is not "sisini wabaya" (we are bad), but "we are those bad ones". This line is simultaneously confirmatory and dissociative of the said Somali dangerousness as it is 'those' as opposed to 'these/we'. In Kenya, when someone or a group of people is described as 'that bad', especially by the youthful demographic, it connotes to being 'extremely good'. That is, 
they are extremely good at whatever they do. That explains why Nasra goes ahead to concretise her point in the conversational rain anecdote and brings it to a conclusion in her second punchline: "But who tells you, you'll see tomorrow?"

Nasra means, and immediately declares, that Somalis are good people, with the insinuation they are good at whatever they do-including (if you will) wreaking havoc because 'Kenyans' have labelled and othered them so. Even in her comic frame, she alienates herself and 'her people' from the audience: they are Kenyans; she (and her people), Somali, their presence in the audience notwithstanding. The words 'kill' and 'finish' are simultaneously denotative of murderous terror and connotative of superb performance. This humour is shocking as it amounts to avowing a debilitating stereotype by the very stereotyped. To the Somalis in the audience, on whom the camera zooms on, it is particularly disconcerting. Some seem to hesitantly join in the laughter because everyone around them is laughing. This is certainly 'uncomfortable humour': "a mode of humour that holds particular powers to discomfort even sympathetic viewers", and bears "an orientation towards the real" (Holm 89). In other words, the Somalis in the audience are uncomfortably implicated in the humour, with the resolution of guilt or innocence heavily weighing on them.

At 'I killed that one, so mercilessly', all the inhibitions of the discomfited seem gone. They appear to have found a vent in the laughter to expel the "pent-up nervous energy" that had been rapidly accumulating since Nasra began her gag. The text is, therefore, only humorous because it has caused them "feelings of anxiety, horror [and/ or] expectation which [have led] to a build-up of psychic stress that [could] not find a proper outlet" (Holm l13). It is still discomfiting because it implicates the audience through persistent reference to reality. As Holm (114) argues elsewhere, this "constantly-referenced reality of the text [...] directly prevents closure; intensifying the stakes of social deviance by assuring the viewers that these are not merely hypothetical or fictional breaches, but actually occurring deviations, while also undercutting any easy sense of detachment that one might feel watching slapstick or a cartoon".

In other words, the comical frame does not exonerate Somalis from their stereotypical inclination to terror. The relationship between the material and the aesthetic is complicated further as the incongruity is neither clear nor resolved. Even the butt is not clearly marked out: is it the Somalis, the Somali in the rain anecdote, the Kenyan who is supposed to alight immediately, the Somali-stigmatising Kenyans, Nasra 'killing it', the G4S guard, or Kenyans in general? The tension is prolonged and deferred to "the extra-textual world as the final arbiters of interpretation" (Holm 114). That is, the interpretation is left to the text-implicated audience. Even so, no one is sure as to how the audience will go about it because, implicated as they are, they are not homogenous. What is clear, however, is that Nasra has infused the stereotype with doubt, and thereby intensified the politics surrounding the treatment of the Somalis by Kenyans and their alleged terror inclination. This is where the political salience of identity lies. It is incumbent upon Kenyans to rethink the stigmatisation by engaging the Somalis or to carry on with it and leave the Somalis to excel at whatever they supposedly do. Somalis are also asked to interrogate themselves. In the meantime, Nasra is proof that Somalis excel at whatever they do, leaving the audience as she does in stitches with an elephant in the room.

Nasra's aesthetic ingenuity allows her to construct her people through her theory-mediated experience and knowledge, a construction that does not in any way make her people and the prejudice they endure fictional. A credible knowledge of the perceptions of Kenyans about Somalis comes through, as Moya would say, in "a more dialectical causal theory of reference in which linguistic structures both shape perceptions of and refer (in more or less partial and accurate ways) to causal features of a real world" (12). The Somalia-based Islamist Al-Shabaab terror group with links to the Al-Qaeda and ISIS (Islamic State of Iraq and the Levant) networks has occasioned untold suffering within Kenyan borders and abroad. Among the perpetrators of these heinous acts-which include suicide bombings and random shootings in targeted buildings at innocent civilians, with Christians bearing the greater brunt-are people of Somali ethnicity.

Subsequently, Kenyans see Somalis, who are predominantly Muslim, as 'innately' prone to terror. It is this stereotype that Nasra confronts head on, with the hilarity that goes with stand-up comedy. Nasra's experience or its construction can be read, in the words of Linda Martín Alcoff, as being acutely aware of how "group identities obscure internal heterogeneity", thereby alerting Kenyans to the fact that no experience is "transparent, [or] theory-neutral" (315), much as the final interpretation and/or resolution of the humour heavily falls on the audience. As such, although Nasra's aesthetic construction does not absolve her people from the stereotyping, she seems to be raising awareness that not all Somalis are dangerous. Moreover, there is need for the people of Kenya to try to 
engage them, thereby placing themselves in a position to pick out the dangerous ones in order to take appropriate action.

The Somali condition in the country is both stereotypical and historical. Tabea Scharrer writes that Somalis have been characterised as "ambiguous citizens" since Kenya's independence because of their lack of integration and their marginalisation within Kenyan society (495). Their ambiguity is aggravated by their confinement to the least developed northern part of the republic that borders Somalia and Nairobi's Eastleigh area, where they are treated with suspicion as refugees taking away commercial opportunities from Kenyans. The rise of their members into high echelons of government and business, coupled with a rising population-which has enhanced their visibility - has worsened matters (502). Over the years, they have been subjected to security checks because they are associated with insecurity and terrorism (497). Worse, they are treated as racially and culturally ill-fitting within the republic, and "are seen as not really wanting to belong [...], as being an economic and political threat, and as not bound enough to Kenya due to their cross-border ties" (506). Nasra has been a victim of discriminatory searches on account of her 'Somaliness' (Irungu). Thus, her ethnicity affords her epistemic privilege, validating her knowledge that she uses to invigorate the politics surrounding the Somali community's situation in Kenya, thereby unsettling the stereotype by disavowing it.

Routine 3:

Baba met Kenya One [...]. In this country we're not tribal. It is only politicians who remind us of our tribes when they are vote-hunting. There's no one in Kenya who wakes up in the morning and wishes that they were not their tribe. "Eh, Jehovah, God, Your Majesty, I thank you that I'm a Luo because God, you've really saved my time because I don't have time to bargain". Nobody! Nobody here in Kiambu wakes up and thanks God that they're not Luhyia. They never say, "Thank you God, for creating me a Gikuyu. You opened my eyes, made me a survivor. Jehovah, I'm the kind of person that can sell air to someone. I don't take that lightly. And you deprived me of the desire for earthly things, and gave me the desire for the earth itself: land. Thank you God, you directed me to Kamakis in 1998, where I bought a piece of land for 30 thousand. Jehovah, the likes of Njuguna mocked me for the imprudence. In 2002, you gave us Kibaki, who struck it with the bypass. Its value shot to 2.8 million. Jehovah, there's a plot I've bought in Isiolo. Open Jubilee's eyes to open LAPSSET.” (Laugh Industry, "Churchill Show S07 Ep29 Thika Road Edition”) ${ }^{3}$

The episode bearing this routine was recorded on 9 March 2018 when President Uhuru Kenyatta and the people's president Raila Odinga shook hands. ${ }^{4}$ Exploiting the event, David (whose surname remains unrevealed) casts doubt on ethnicity, the construct that has occasioned devastating divisions in Kenya every presidential electioneering period, where the winner seemingly takes it all, usually after whipping 'tribal emotions' across the country through assembling 'tribal' chiefs, who horse trade their people to him. David contends that 'tribal' affiliation/ belonging is never a problem until politicians weaponise it for votes. Simply put, no Kenyan is ashamed of their ethnicity. David demonstrates this by wearing a Luo persona, Odinga's ethnicity. 'Baba' is his famed nickname, connoting to the father of the Luo and/or the whole nation and multi-party democracy. David observes that no Kenyan thanks God for their ethnic extraction. Employing the Kikuyu category, to which he himself and Kenyatta ('Kenya One') belong, David politically sets Kenyatta and Odinga apart as did the politics that led to the 'handshake' moment. His diction is pertinently subtexual, implicating him in the gag too.

Nonetheless, David dramatizes 'his people's' stereotype: they are cunning in their obsessive pursuit for money and land. However, for all these 'debilitating' attributes, none thanks God for creating them Kikuyu and not Luhyia, for instance. They contingently found themselves among the Kikuyu, who supposedly behave as stereotyped. David's ostensible appreciation of Kikuyu cunningness cloaks the stereotype in ambivalence. It is hard to discern his position in relation to the stereotype. Yet, it is not him in the stereotype, but an aesthetic persona. Still, the persona is simultaneously him and not him. The persona's 1998 'imprudence' hugely paid off to the shame of his fellow Kikuyu detractors. Although he does not thank God for his 'Kikuyuness', he is grateful for Kibaki, who turned his rocky parcel into gold, literally. Perhaps had Kibaki not been Kikuyu, the said persona would not have struck the gold. That is why he hopes God makes the Jubilee duo of Uhuru Kenyatta and William Ruto, Kibaki's anointed successor, just as 'wise'.

Without invalidating the said Kikuyu stereotype, David authenticates the pervasive narrative that it is God who anoints leaders, a perception that politicians often fraudulently appropriate to paint themselves as God-chosen among masses brainwashed with Pentecostal prophetism (David and Katola 54). Nevertheless, David does not explicitly insert himself into the anecdote. Rather than identify with the Kikuyu nation, he holds it at an aes- 
thetic distance, thereby infusing the stereotype with doubt and allotting the burden of resolution to the audience just as Nasra does. He, however, affirms the stereotype that Kikuyus are obsessed with the pursuit of wealth, whichever the manner, and not as a group, but as individuals. This shreds the blanket of group homogeneity, highlighting intra-group heterogeneity. Every ethnicity has people who exploit opportunities. Thus, David simultaneously unsettles and (re)settles the stereotype through a political aesthetics.

\section{Conclusion}

In this article I have tried to show that Churchill offers a platform on which the ordinary people's quotidian and the historical are explored away from the state's officially sanctioned histories. Through an aesthetics of escapism that cloaks the show in a 'just for laughs' mould, critical issues affecting Kenyan society are addressed in mock signification. Further, I have attempted to demonstrate that transglossic language practices help engender new meanings by executing a transgressive politics that recalibrates the country's language practices. Such a politics is embodied in the show's postmodern humour aesthetic that upsets stereotypes by infusing them with ambivalence in order to fashion a new notion of Kenyannes constitutive of a spirit of 'we-ness'.

\section{Acknowledgements}

This article is based in part on my on-going doctoral thesis made possible with the financial support of the Urban Connections in African Popular Imaginaries at Rhodes University. Grant number 31600707.

\section{Notes}

1. To distinguish between Churchill, the show, and Churchill, the founder/host, I use italics for the former and regular font for the latter.

2. Anthony Ilona defines mock signification as "the deliberate, performed process of making derisive meaning". Drawing on the mock drama staged by Hamlet, Ilona argues that the process "is evaluative in its effect [and] as Hamlet himself is noted to say, "[t]the play's the thing wherein I'll catch the conscience of the King"' (48).

3. The Lamu Port and Lamu-Southern Sudan-Ethiopia Transport corridor meant to link Kenya, Southern Sudan, and Ethiopia by ports, pipelines, roads, and railways.

4. Following the hotly contested 2017 election that was nullified by the Supreme Court, Uhuru Kenyatta was sworn in in an elaborate state function on 28 November 2017 at Kasarani Stadium following the repeat election in which he ran against himself garnering 98\% of the vote while Raila Odinga was sworn in 'by the people' on 30 January 2018 at Uhuru Park.

\section{Works Cited}

Alcoff, Linda Martin. "Who's Afraid of Identity Politics?" Reclaiming Identity: Realist Theory and the Predicament of Postmodernism, edited by Paula M. L. Moya \& Michael R. Hames-García. Berkeley U of California P, 2000, pp. 1-28.

Atieno-Odhiambo, E. S. "Hegemonic Enterprises and Instrumentalities of Survival: Ethnicity and Democracy in Kenya." African Studies vol. 61, no. 2, 2002, pp. 223-49.

David, Stephen Kioko \& Michael T. Katola. "The Church-State Relationship in Kenya after the Second Liberation Struggle." Journal of Educational Policy and Entrepreneurial Research, vol. 3, no. 12, 2016, pp. 44-59.

Dovchin, Sender, Alastair Pennycook \& Shaila Sultana. Popular Culture, Voice and Linguistic Diversity: Young Adults On-and Offline. Palgrave Macmillan, 2018.

García, OfeLia. "Countering the duel: Transglossia, Dynamic Bilingualism, and Translanguaging in Education." The Globallocal Interface and Hybridity: Exploring Language and Identity, edited by Rani Rubdy \& Lubna Alsagoff. Multilingual Matters, 2014, pp. 100-18. DOI: https://doi.org/10.21832/9781783090860-007.

Gecau, Kimani. "History, the Arts and the Problem of National Identity: Reflections on Kenya in the 1970s and 1980s." National Identity and Democracy in Africa, edited by Mai Palmberg. Pretoria Capture, 1999, pp. 8-39.

Githatu, M. Mary \& Furaha Chai. "Discursive Structure of Humour in Stand-up Comedy Kenya: Discourse Topics and Stylistic Devices in Churchill's Performances." International Journal of Language and Linguistics vol. 3, no. 6, 2015, 409-15. DOI: https://doi.org/10.11648/j.ijll.20150306.24.

Holm, Nicholas. Humour as Politics: The Political Aesthetics of Contemporary Comedy. Cham Palgrave Macmillan, 2017.

Hornsby, Charles. Kenya: A History since Independence. New York I. B. Tauris, 2012.

Ilona, Anthony. "Laughing through the tears': Mockery and self-representation in V. S. Naipaul's A House for Mr. Biswas and Earl Lovelace's The Dragon Can't Dance." Cheeky Fictions: Laughter and the Postcolonial, edited by Susanne Reichl \& Mark Stein. Rodopi, 2005, pp. 43-60.

Irungu, Anthony. "Somali comedian Nasra Yusuf is 'killing stereotypes'.” BBC News. 2 Feb. 2019. www.bbc.com/news/av/ world-africa-47071136/.

Laugh Industry. "Churchill Show-All White Edition." YouTube. Uploaded by Churchill Show. 7 Jul. 2015. https://www. youtube.com/watch?v=FGMNqNAvMtI\&et=272s. . "Churchill Show: Moi Day edition." YouTube. Uploaded by NTV Kenya. 14 Oct. 2018. https://youtu.be/RT-cYZUD6go. . "Churchill Show S7 Ep29 Thika Road Edition." YouTube. Uploaded by Churchill Show. 26 Mar. 2018. www.youtube. com/watch?v=Gmd4pqhRXDk. 
“Churchill Show S7EP30 KICC." YouTube. Uploaded by Churchill Show. 1 Apr. 2018. https://www.youtube.com/ watch?v=FlgpWRXkmZM.

Ligaga, Dina. "Ethnic stereotypes and the ideological manifestations of ethnicity in Kenyan cyber communities." African Insight vol. 39, no. 1, 2009, pp. 72-85. . Women, Visibility and Morality in Kenyan Popular Media. NISC 2020.

Moya, M. L. Paula. "Introduction: Reclaiming Identity." Reclaiming Identity: Realist Theory and the Predicament of Postmodernism, edited by Paula M. L. Moya \& Michael R. Hames-García. Berkeley U of California P, 2000, pp. 1-28.

Michieka, Martha \& Leonard Muaka. "Humor in Kenyan comedy." Diversity in African Languages: Selected papers from the 46th Annual Conference on African, edited by Doris L. Payne, Sara Pacchiarotti \& Mokaya Bosire. Language Science, 2016, pp. $55-76$.

Musila, A. Grace. “The Redykyulass Generation's intellectual interventions in Kenyan Public Life.” Young: Nordic Journal of Youth Research vol. 18, no. 3, 2010, pp. 279-99.

Ndonye, M. Michael, Felicia Yieke \& James Ogola Onyango. "Ethnicity as Discursive Construct in Kenyan Televised Comedy: Humorous Harm?" The Journal of Pan African Studies vol. 8, no. 3, 2015, pp. 44-60.

Ndonye, M. Michael, Phylis Bartoo \& Josephine Khaemba. "The Tyranny of Televised Comedy: Modeling Ethnic Relation through 'Churchill Live Show' in Kenya." Scholars Journal of Arts, Humanities and Social Sciences vol. 3, no. 3A, 2015, pp. 605-11.

Nyairo, Joyce \& James Ogude. "Specificities: Popular Music and the Negotiation of Contemporary Kenyan Identity: The Example of Nairobi City Ensemble." Social Identities vol. 9, no. 3, 2003, pp. 383-400.

Paul, William. "No Escaping the Depression: Utopian Comedy in Frank Capra's You Can't Take it with You (1938)." A Companion to Film Comedy, edited by Andrew Horton \& Joanna E. Rapf. Wiley-Blackwell, 2013, pp. 273-93.

Scharrer, Tabea. "'Ambiguous citizens': Kenyan Somalis and the question of belonging." Journal of Eastern African Studies vol. 12, no. 3, 2018, pp. 494-513. DOI: https://doi.org/10.1080/17531055.2018.1483864.

Shilaho, K. Westen. Political Power and Tribalism in Kenya. Cham Palgrave Macmillan, 2018.

Sultana, Shaila \& Sender Dovchin. "Popular Culture in Transglossic Language Practices of Young Adults." International Multilingual Research Journal vol. 11, no. 2, 2017, pp. 67-85. DOI: https://doi.org/10.1080/19313152.2016.1208633.

Wanjala, Alex Nelungo. "From Swahili to Sheng: Documenting the Emergence of a New Ethne in Kenyan Society." Phoenix: Sri Lanka Journal of English in the Commonwealth vol. 15, 2019, pp. 81-9. 